\title{
$-19-$ \\ ECONOMIC, PETROLEUM, AND GROUND-WATER GEOLOGY
}

J. H. MCKILLOP, Director of Mineral Resources for the DEPARTMENT OF MINES Or NEWFOUNDLAND and L. M. CUMMING of the rSC report on the mineral exploration in Newfoundland. Interest in the geology of the area reached an all-time peak during the 1964 field season. A magnetometer and gravity survey is currently underway on the Crand Banks. The survey is conducted by HUNTING SURVEY CORPORATION LIMITED for PAN AMERICAN PETROLEUM LIMITED. The program is part of an exploration project designed to evaluate the off-shore oil potential of the area. We wish them success! The Mineral Resources Division of the Newroundland Department of lines, Agriculture and Resources is currently carrying out a study of diatomite occurrences, particularly on the Nvalon peninsula of Newfoundland. The program is designed to explore the potential for commercial deposits of this type of deposit. The study involves mapning, detailed sampling using a swedish soil sampler, and laboratory studies. This study of diatomite occurrences began during the 1964 field season and is expected to run through another season.

COLDEN EAGLE OIL AND GAS LIMITED investigated petroleum prospects of west coast carbonates during the summer of 1964. H. CORKIN of Calgary, and E. HESKETH of New York did the work.

The $\%$. J. BOYI.EN ENGINEERING OFFICES LIMITED, Toronto, are active in Newfoundland. E. HAMILTON directed a geochemical survey on part of the Upper Humber Piver Carboniferous belt. B. B. BPOWN investigated the geology and geochemistry of the Paleozoic lowland concession south of Portland Creek.

JOHN F. JONES has initiated an active program for the newly established CROUNDWATER DIVISION of the NOVA SCOTIA DEPARTMENT OF MINES. The following is a brief summary of the Division's activities since June of 1964 .

\section{Action Requests}

The Division is co-operating with provincial and federal government agencies in helping individuals, municipalities, and industries to obtain suitalle water supplies. Of particular note is the finding of large supplies for the new SCOTIAN COLD FOOD PRODUCTS plant at Coldbrook (largest screened well in Nova Scotia) and the CHETICAMP CO-OPERATIVE TISHING PLANT in Cape Breton Is land.

Field and Laboratory programs

An extensive summer field program has been started in cooperation with the NOVA SCOTIA RESEARCH COINDATION to evaluate groundwater rescurces of the province. Field parties have been active th this past summer in the Annapolis Valley and in Inverness County, Cape Breton Is land. These investjgations include studies of surficial geology, subsurface stratigranhy, anuifer evaluation, groundwater chemistry, and geophysical exploration to locate possible aquifers. These particular field projects are ioint ventures between the PROVINCIAI COYERNMENT and the ACRICUURA REHABILITATION AND DEVELOPMENT ACT. 
THE DEPARTMENT OF MINES has obtained a water we 11 drill. Facilities for chemical analysis of water have been established at Truro by the NOVA SCOTIA WATER NUTHORITY.

Basic Data Collection and Compilation

Drilling and instrumentation has started to establish an observation-well network in selected aquifers within the province. This will permit correlation of short and long term fluctuations of water levels with climatic change and water use. An inventory of existing water wells in the province and their geological environment has been initiated. The data is being assembled and recorded on maps and keysort punch-cards for ready use and classification. The new WELL DRILLERS LICENSING ACT of January, 1965, will aid this study. Water-well drillers are required to file logs of all new wells drilled in the Province.

$M r$. JONES has been appointed the Province's representative to the SUBCOMMITTEE ON HYDROLOGY OF THE ASSOCIATE COMMITTEE ON GEODESY AND GEOPHYSICS, the NATIONAL RESEARCH COUNCIL OF CANADA. This subcommittee was organized in 1957 to review hydrologic research in Canada and to stimulate research in this field. Until that time, there was no organization in Canada through which those interested in the various branches of hydrology could exchange ideas and compare notes on their own research projects. This subcomittee has been aute active since its incertion and has sponsored symposia on spillway design floods, evaporation, groundwater, and experimental watersheds. Planning is underway now on a fifth symposium on hydrology.

Future plans for the Division include an expanded field program and co-operation in different projects as part of Nova Scotia's contribution to the INTERNATIONAL HYDROLOCIC DECADE. Additional stafe will be obtained this spring.

Urban growth and industry attraction depend a great deal on suitable groundwater supplies. The active program of the Division is of obvious economic importance to the Atlantic area and to its future growth. 